\title{
Stingless bee honey (Hymenoptera, Apidae, Meliponini): a review of quality control, chemical profile, and biological potential
}

\author{
Edineide Cristina A. SouzA ${ }^{1}$, Cristiano Menezes $^{2}$, Adriana Flach ${ }^{1}$ \\ ${ }^{1}$ Programa de Pós-graduação em Biodiversidade e Biotecnologia da Rede Bionorte, Universidade Federal de Roraima, \\ Boa Vista, RR, Brazil \\ ${ }^{2}$ Embrapa Meio Ambiente, Jaguariúna, SP, Brazil
}

Received 3 April 2020 - Revised 2 July 2020 - Accepted 3 August 2020

\begin{abstract}
Products made by bees are well-known for their beneficial properties and nutritional value. This association has been proven by scientific studies that describe their composition and biological activities. The aim of this study is to portray the state of the art on research regarding stingless bee honey. The search for standards that guide the trade of these products is still portrayed as a future perspective, since there are significant differences in relation to honey from Apis mellifera and it often requires additional treatments.
\end{abstract}

stingless bees / honey quality / chemical composition

\section{INTRODUCTION}

Stingless bees, also called meliponines, native, or indigenous bees, comprise a wide group of eusocial bees and present a range of variations in behavioral aspects, communication systems, foraging strategies, population densities, and nest architectures, among others (Nogueira-Neto 1997). More than 500 species of stingless bees have been described and 61 genera are distributed in Latin America, Australia, Africa, and tropical parts of Asia.

The use of rational breeding techniques, knowledge of the explored flora, the implementation of management techniques, and artificial feeding have allowed the expansion of meliponiculture (Jaffé et al. 2015). Many species

Corresponding author: A. Flach, aflach@gmail.com Manuscript editor: James Nieh are popular and are raised to obtain products which generate jobs and income and, at the same time, maintain biodiversity (Kerr et al. 2001; Imperatriz-Fonseca and Nunes-Silva 2010; Contrera et al. 2011; Ollerton et al. 2011; Freitas and Nunes-Silva 2012; Bartelli and NogueiraFerreira 2014). In Brazil, many tree species and agricultural crops are pollinated by these bees and their effective pollination performance has been confirmed for more than 30 different agricultural crops (Heard 1999; Slaa et al. 2006; Castro et al. 2006). The importance of Apis mellifera in pollination has already been widely reported (Blettler et al. 2018) whereas for stingless bees, studies have been conducted to evaluate pollination efficiency considering the productive increase of cultivars, and the results indicate that these bees are considered promising for use as commercial pollinators (Roselino et al. 2009, 2010; Kiatoko et al. 2014).

In the Amazon region, there is a great diversity of bees, which can be attributed to the favorable 
conditions, such as warm weather and flora rich in species that supply nectar, pollen, and resins. In these regions, the honey has been the main product of extraction; however, studies have shown that many species of meliponines have considerable productive potential for propolis, geopropolis, batumens, and cerumens, in addition to pollen (Contrera et al. 2011).

In the last decade, researchers and environmentalists from around the world have shown great concern about the decline in the population of managed and wild pollinators (Potts et al. 2016), and have promoted a significant scientific advance related to the theme of bees. Many campaigns are being carried out to publicize their importance to human existence and in the maintenance of the ecosystem, and thus provoke a wave of worldwide interest on the subject and open new horizons for scientific research, especially regarding stingless bees, which are still little studied. Some recent reviews have been published on topics such as propolis (Anjum et al. 2018; Popova et al. 2019), reproductive behavior (Vollet-Neto et al. 2018), and palynological analysis (Souza et al. 2019). This review aims to discuss what the scientific community knows about honey from stingless bee honeys, when used not only as food but also its functional properties.

\section{HONEY}

Most studies regarding honey have been carried out with Apis mellifera, since this species has adapted to different regions around the world. However, the literature extolls the virtues of the different characteristics of honey from stingless bees, especially in relation to its moisture content, peculiar flavor, and more pronounced aroma (Alves et al. 2005).

The honey production strategy of $A$. mellifera consists of removing the moisture from the nectar to a certain level that the microorganisms can no longer reproduce and with that it can be stored for many years without deteriorating and maintaining practically the same characteristics of color, flavor, aroma, and physicochemical properties. Bees remove moisture by using their wings and add enzymes with the function of digesting sugars and conserving honey. Honey is stored in combs made of wax produced by the workers' glands and after being closed, the honey no longer has contact with air (Seeley 1985).

The strategy used by stingless bees is different. They dehydrate honey to a reasonable, however, specific level (Vit et al. 1994; Souza et al. 2006). After being stored, microorganisms, mainly bacteria of the genus Bacillus and yeasts, will consume part of the sugar and transform it into alcohol through anaerobic fermentation and then this alcohol is transformed into acetic acid through aerobic fermentation. Sugar can also be transformed into other types of acids (and other byproducts) through other types of non-alcoholic fermentation (Gilliam et al. 1985; Gilliam et al. 1990; Menezes et al. 2013). This fermentation alters the characteristics of the honey and is very specific, since each bee species has its own microbiome and the processing dynamics are different. There is evidence that microorganisms also add enzymes and other compounds to honey that can contribute to its conservation and digestion of nutrients (Menezes et al. 2013). In addition, the cerumen pot, in contrast to the Apis mellifera honeycomb, gradually transfers the aromas from the pots to the honey and, via their intensity, superimposes them on the honey, thus creating the specific identity of the bee species. It is possible that bioactive substances, such as antibiotics and antioxidants, are being incorporated into honey in these processes.

The composition of honey depends, among other factors, on the plant sources from which it is derived, the species of the bee, the physiological state of the colony, the state of maturity of the honey, and the weather conditions during the harvest (Campos et al. 2003). The honey of the meliponines species has as its main characteristic, the highest acidity and the highest water content (moisture), which makes it less dense than the honey from Africanized bees (A. mellifera). The chemical composition has been little studied, and the studies that exist are limited to the quantitative determination of its phenolic and flavonoid compounds.

Due to the particularities presented by honey from native bees, studies aiming at characterization have been carried out, with the objective of 
determining their identity and controlling possible adulterations. These studies are important for the elaboration of a legislation that meets the quality control of honey of meliponines (Vit et al. 1994; Souza et al. 2006). In Brazil, the legislation regarding honey is intended for the classification of honey from A. mellifera (Brazil 2000) and does not deal with the characteristics of the product of stingless bees. Recently, however, some Brazilian states such as Bahia (Brazil 2014) and São Paulo (Brazil 2017) have defined specific parameters for honeys from stingless bees, aiming at quality control and the formalization of the sale of this product. With this, establishments that aim at the processing of honey and are accredited by the Federal Inspection Service are already managing to overcome the pre-existing bureaucratic barriers, register the honey from stingless bees, and commercialize it in the formal market.

\section{PHYSICO-CHEMICAL PROFILE OF HONEYS FROM STINGLESS BEES}

Most of the physical-chemical profiles were performed with bees occurring in Brazil, and the most studied honey of native bees is that from bees of the genus Melipona, as can be seen in Table I. Analyses of honey from Melipona scutellaris harvested in different locations: Brejo Paraibano region, northeastern Brazil (Evangelista-Rodrigues et al. 2005), in Bahia (Souza et al. 2009b), Paraná (Nascimento et al. 2015), and in Santa Catarina (Biluca et al. 2016) showed that there is some variation in the content of hydroxymethylfurfural (HMF) between samples; this parameter indicates deterioration levels of honey. Taking as a reference the limits established in the standards applied to A. mellifera honey, the values obtained for the samples of $M$. scutellaris honeys would be in conformity for the free acidity index, diastase activity, HMF, sucrose, and ash content.

Regarding the level of free acidity of honey from the genus Melipona, the honey from Melipona flavolineata, harvested in Brazil, had the highest index, whose value was 143.67 meq/ $\mathrm{kg}$ (Lemos et al. 2017), while Melipona quadrifasciata anthidioides, produced honey with an index of $17 \mathrm{meq} / \mathrm{kg}$, also harvested in
Brazil (Duarte et al. 2018). For the dehumidified honey of Melipona quadrifasciata, an index of $7.5 \mathrm{meq} / \mathrm{kg}$ was obtained (Carvalho et al. 2009). Of the total, $27 \%$ of the samples evaluated are above the required standard due to the fermentation that occurs naturally in honey from stingless bees, so this parameter is not recommended for use in assessing the quality of honey from stingless bees.

Melipona asilvai honey, although harvested in the Northeastern region of Brazil, has significant differences in HMF content, conductivity, and acidity (Souza et al. 2004; Souza et al. 2009a; Duarte et al. 2018). The exact period of the harvest and analysis of these samples must be considered in order to justify the differences.

Comparing the data in the literature (Table I) with the legislation for A. mellifera, it can be seen that the vast majority of the data obtained in the studies exceed the standard limits established for Apis mellifera honey, where the high moisture and acidity (Brazil 2000), humidity and free acidity are notable (Codex Alimentarius Commission 2001). Ash, sucrose, HMF contents, and diastase activity are less problematic, but eventually samples are outside the established limits. Therefore, the future regulations should review the standard limits to fit the majority of studied stingless bee honeys.

The laws of the state of São Paulo, Bahia, and Amazonas, which are aimed at regulating the quality of Meliponini honeys, represent a great advance in this issue in Brazil. There are still some gaps that need to be addressed, and probably changed in the future, but they are already allowing stingless bee keepers and honey industries to sell Meliponini honey in the official market. One of the parameters that should be revised is the free acidity levels. São Paulo and Bahia laws kept the same limit established for Apis mellifera honey $(50 \mathrm{meq} / \mathrm{kg})$ and Amazonas increased the tolerance to $80 \mathrm{meq} / \mathrm{kg}$. This parameter is used to evaluate if the honey of apiculture industry has fermented. Because of natural fermentation that occurs in Meliponini honey (Menezes et al. 2013), it does not make much sense for stingless bee industry. About $30 \%$ of the samples are above the limit of $50 \mathrm{meq} / \mathrm{kg}$ and eventually higher than $80 \mathrm{meq} / \mathrm{kg}$. For the content of reducing sugars, the 


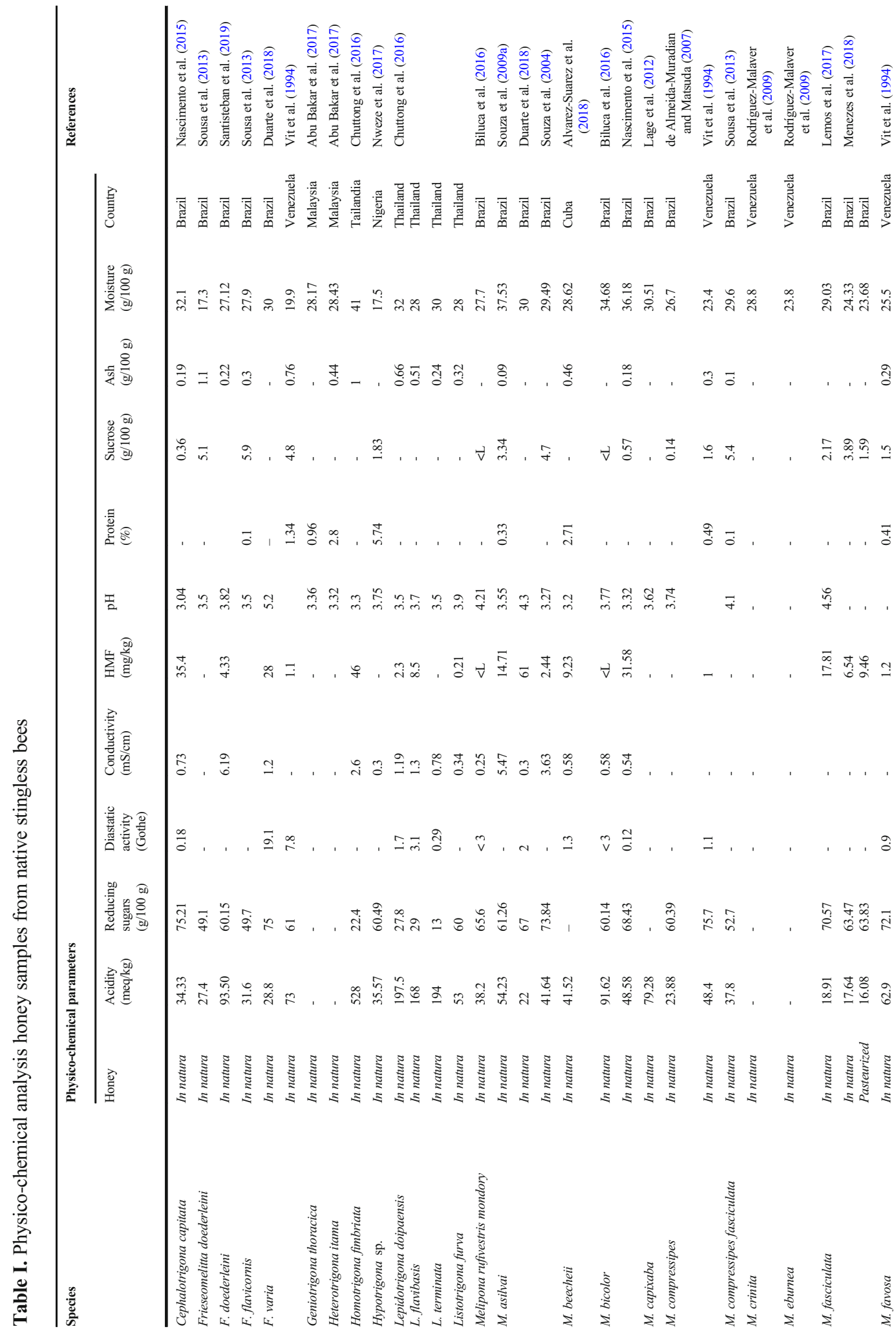




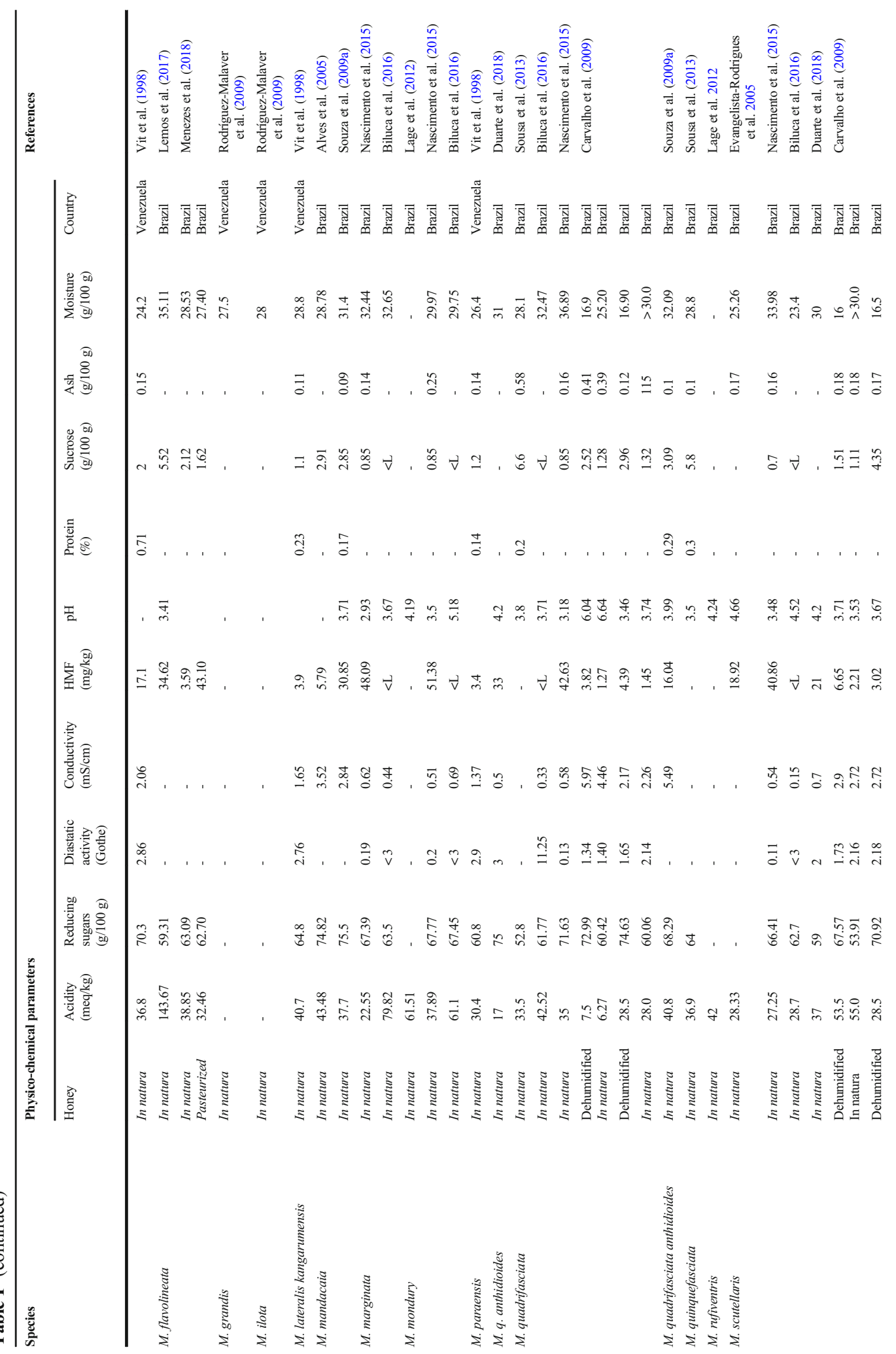




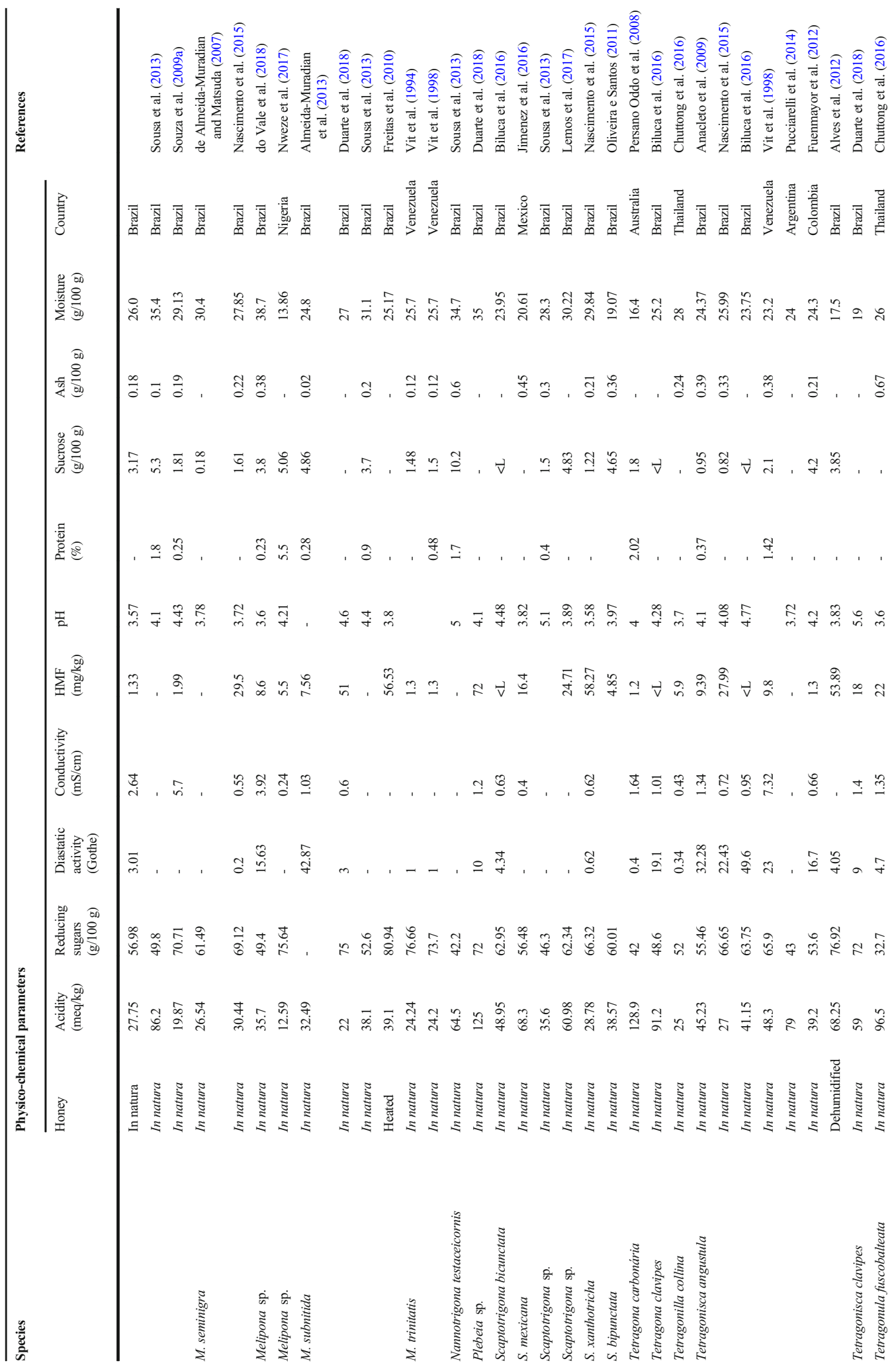




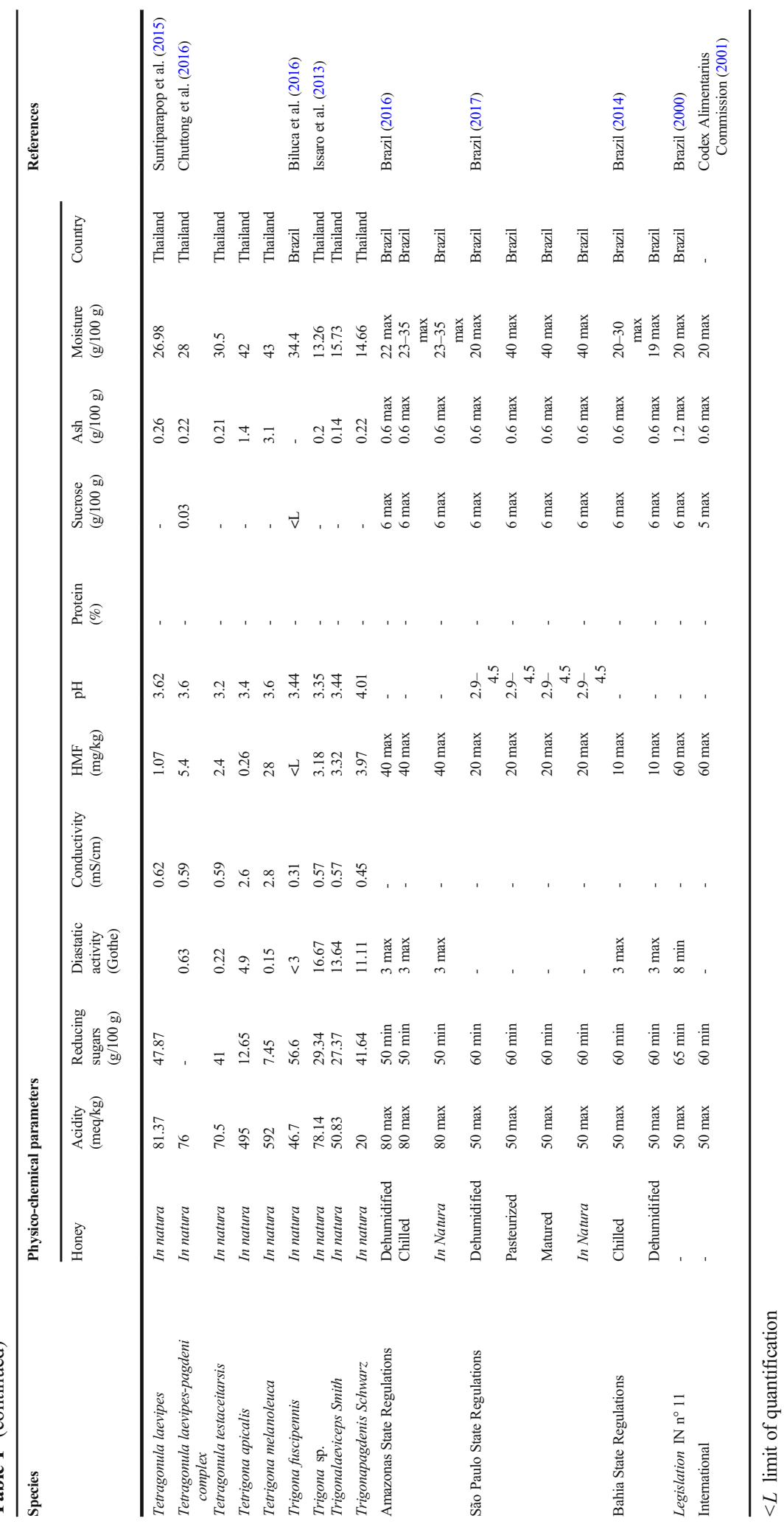


value determined by these regulations is less than $50 \mathrm{~g} / 100 \mathrm{~g}$. For the moisture level, it can be observed in the regulations that the levels required for fresh and chilled honey are allowed to reach a maximum of $35 \mathrm{~g} / 100 \mathrm{~g}$, while the proposals allow for up to $40 \mathrm{~g} / 100 \mathrm{~g}$. These differences may be associated with the floral origin of the honeys.

When comparing the physico-chemical parameters determined with European (Codex Alimentarius Commission 2001) and Brazilian legislation (Brazil 2000), the acidity index, reducing sugars, diastase activity, HMF, and humidity are the ones that present quite different values from those established. Of the 106 studies listed in Table I, 29 had acidity levels above the reference value, 31 contained levels lower than those established for reducing sugars, over 33 had diastase activity below what is permitted by legislation, 12 had HMF levels higher than established levels, and 82 humidity levels were above those stipulated. For sucrose and ash contents, in the vast majority of studies, the values are in accordance with legal limits. When the comparison takes place with what the Brazilian states of Amazonas, São Paulo, and Bahia define as standard, we can observe that this quantity is smaller, only 5 samples of honey provided values above those stipulates for acidity levels, for reducing sugars, 15 of them did not meet the regulations, for diastase activity, even though the proposals establish a maximum of 3 on the Gothe scale, 27 presented higher values. For the HMF content, 10 provided values above the regulations and for humidity, only 2 honey samples were not in compliance. Analyzing the data, it can be noted that what makes the honey of native bees and Apis mellifera considerably different are not only the high levels of acidity and humidity but also other factors as well. For example, the content of reducing sugars and diastase activity shows significant discrepancies from those stipulated for non-stingless bee honey.

Almeida-Muradian et al. (2013) studied samples of honeys from Apis mellifera and Melipona subnitida and found that the honey of A. mellifera showed values within the established limits, while that of the stingless bee presented values for diastase activity 5 times greater than the minimum stipulated, and the honey moisture was also slightly above the norm (Table I). The results of the palynological analysis showed that even though they were subjected to the same flora, bees of different species access different plant sources.

Table I also includes data from different methods used in the treatment of honey. The expressive moisture content creates product instability over time, as it is very susceptible to fermentation. To overcome the problems arising from this, good harvesting practices are necessary, and these should aim at reducing contamination by microorganisms. Once harvested, some processing methods can be applied to assist in the conservation of this product. These are refrigeration, dehumidification, pasteurization, and maturation (Venturieri et al. 2007; Contrera et al. 2011).

Freitas et al. (2010) used heating in order to evaluate the physico-chemical parameters of the honey from Melipona subnitida in its natural form. After heating in an oven at $70{ }^{\circ} \mathrm{C}$ for different periods, the results indicated that the heat treatment decreased the acidity and humidity; however, the content of HMF and reducing sugars increased significantly. When compared with regulation proposals, with the exception of the HMF content, the other parameters were in accordance with the established levels.

Alves et al. (2012) evaluated the physicochemical and sensory stability of the dehumidified honey of Tetragonisca angustula. The results showed good physico-chemical stability for the parameters of humidity, reducing sugars, apparent sucrose, $\mathrm{pH}$, acidity, and HMF during a storage period of 180 days. However, only the $\mathrm{pH}$ and humidity corresponded to the values established in the regulation proposal by Camargo et al. (2017) for dehumidified honey. In comparison with the regulations of the Amazonas state, the parameters for acidity, reducing sugars, and humidity are in accordance.

Menezes et al. (2018) adopted pasteurization as a measure to minimize the proliferation of microorganisms in the honey from M. fasciculata and $M$. flavolineata. The process significantly influenced the moisture, $\mathrm{pH}$, apparent sucrose, and HMF of the honeys, but did not influence acidity, ash, and reducing sugars.

The results show that when the moisture content of honey from stingless bees is adjusted, the 
other parameters are altered. Therefore, there is no treatment that meets the peculiarities of the honey produced by these bees nor does it make any treatment universally suitable for quality parameters. Thus, proposed regulations already admit specific values for the parameters in the different forms of processing. Carvalho et al. (2009) studied Melipona honeys which had been harvested in different places and subjected to the dehumidification process. The honey produced by M. quadrifasciata, which was harvested on the island of Itapara and compared in natura with dehumidified form, showed an increase in the acidity index, reducing sugars, HMF, and sucrose, and a decrease in the diastase activity values, $\mathrm{pH}$, and, consequently, humidity. These changes are compatible with what is expected for this treatment. This profile was also observed in the samples from Costa do Sauipe, Bahia State, Brazil. The honeys showed relevant differences for some parameters, such as the total acidity index which was lower for honey harvested on the Island of Itapara. For this honey, the $\mathrm{pH}$ is lower than for the honey harvested on the Costa do Sauipe. In relation to the honey from M. scutellaris, honey harvested in Tucano showed alterations in the content of sucrose and HMF, and showed an increase after the treatment, whereas the one harvested in Serrinha presented an increase in the levels of sucrose, HMF, and reducing sugars. The values for most of the evaluated parameters are in accordance with those established in the proposals and in the regulations of the state of Amazonas.

The studies also gather a significant amount of data on the honeys of species of the genera Scaptotrigona and Tetragonisca, and for the later of these two genus, seven of the eight studies were carried out with $T$. angustula species.

\section{METABOLITES AND BIOLOGICAL ACTIVITY OF HONEYS FROM STINGLESS BEES}

The literature has little data regarding the chemical composition of honey from stingless bees, and studies tend to focus on the quantification of phenolics compounds and flavonoids. These determinations are supported by positive correlations between the presence of these compounds with antioxidant activity (Table II).

The phenolic content was the most commonly determined parameter in the honeys studied so far (Table II). The phenolic content of M. subnitida was $0.6 \mathrm{mg}$ AGEq $100 \mathrm{~g}^{-1}$ in honey from the state ofAmazonas (Brazil) and 854.62 mg AGEq $100 \mathrm{~g}^{-1}$ in honey from the state of Sergipe (Brazil). Other studies with other species have also revealed different phenolic contents for M. fasciculata and M. flavolineata (Oliveira et al. 2012), as well as for M. s. merrillae (Silva et al. 2013). These differences in content for the same species indicate that it will be difficult to create an adequate parameter for quality, since the flora is very diverse. Perhaps the way forward is to create a geographic seal after monitoring the parameters at different times of the year and for several years.

Different methods were used to determine the antioxidant capacity of stingless bee honeys, with DPPH and ABTS free radical scavenging being the most commonly used. When the data in Table II for the activity using these two methods is analyzed, it appears that the values vary widely.

Ávila et al. (2019) evaluated the antioxidant action of meliponine honeys using three different methods and the ORAC method the values were more expressive.

The study by Duarte et al. (2018) with 31 samples of meliponine honey from the same meliponary, in the state of Alagoas, Brazil, describes the differences in the content of phenolic compounds and flavonoids, which suggests preferences for different types of nectar.

For the honey of M. s. merrillae harvested in different locations in the state of Amazonas, differences in phenolic content were observed. Samples obtained in Pauíni and Maués showed the highest levels: $64.0 \pm 0.03$ and $66.0 \pm$ $0.05 \mathrm{mgAGEq} 100 \mathrm{~g}^{-1}$, respectively. However, these samples were expected to have better antioxidant activity, but compared with those with lower concentrations, there was no significant difference (Silva et al. 2013). The authors also carried out the characterization of this stingless bee honey and detected by means of highperformance liquid chromatography (HPLC) the presence of 14 phenolic compounds in the ethyl acetate fraction. The presence of some of the 


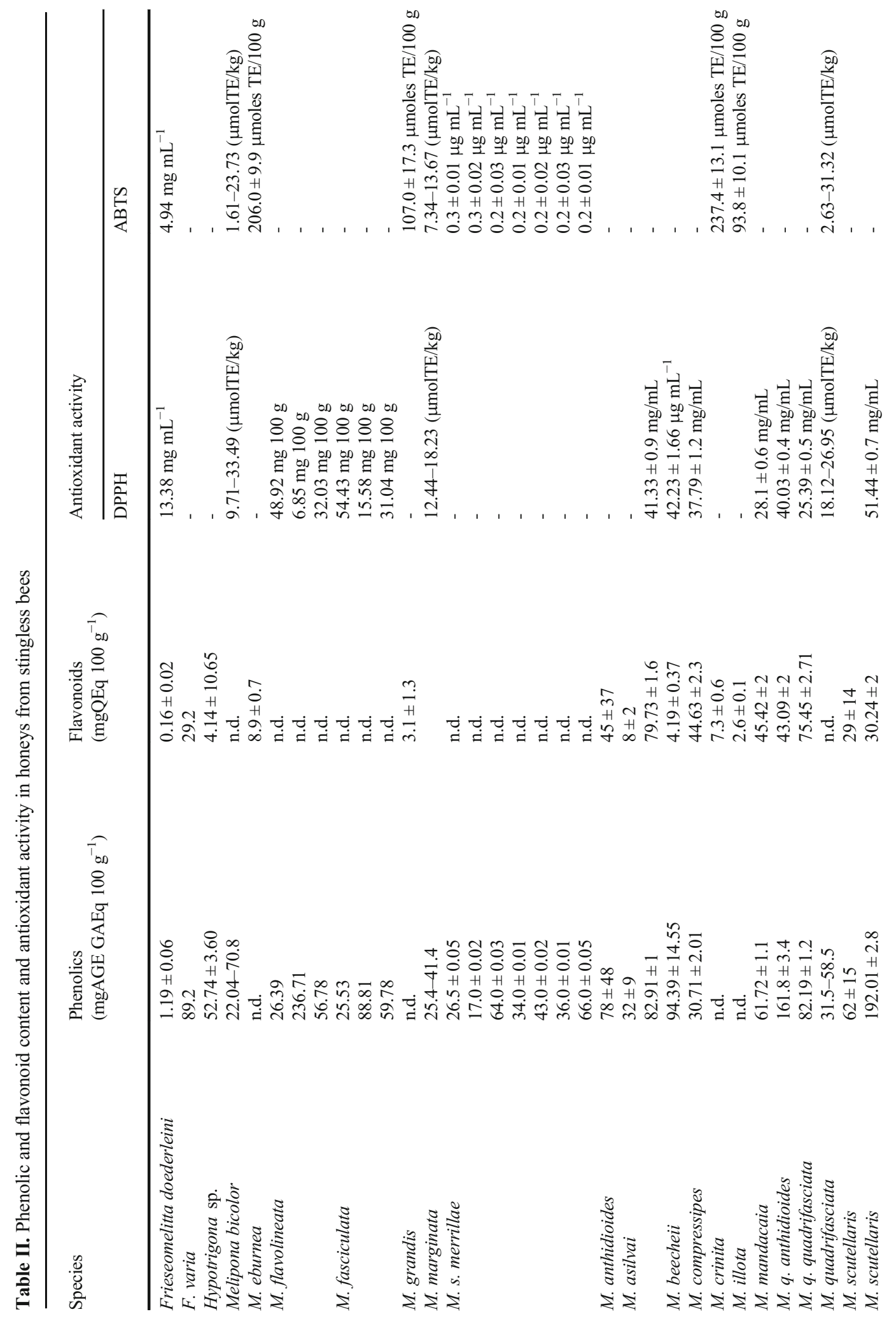




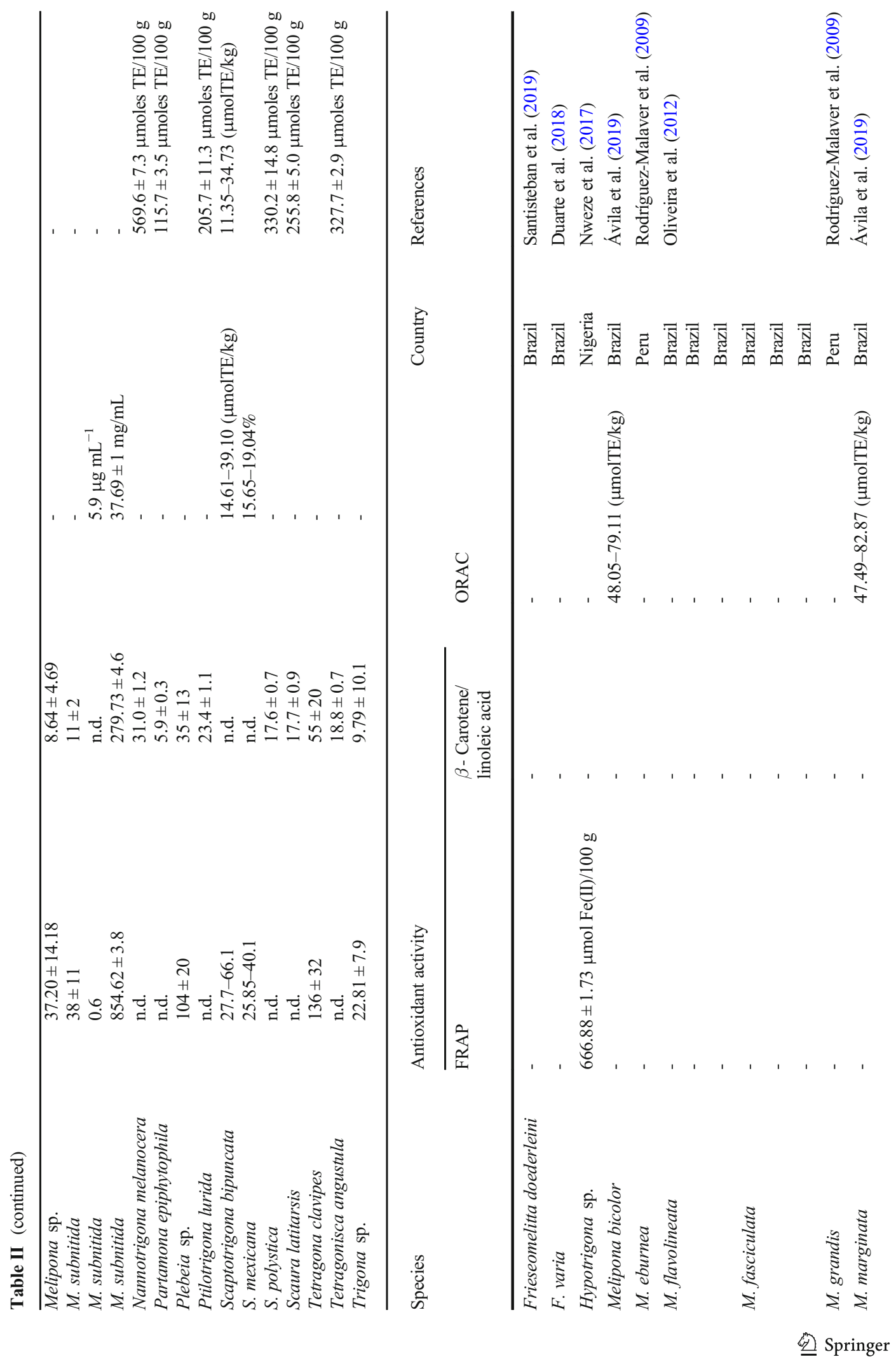




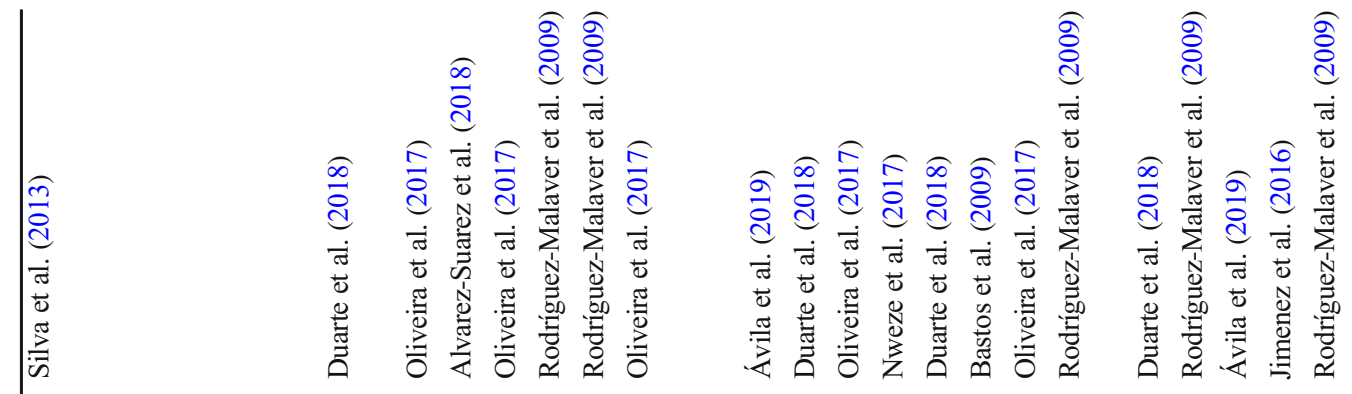

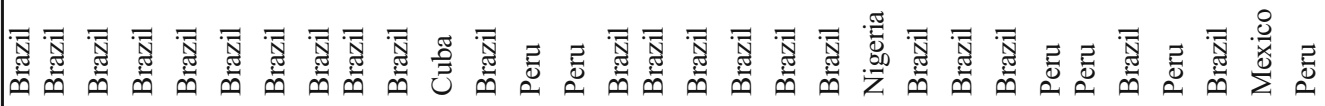
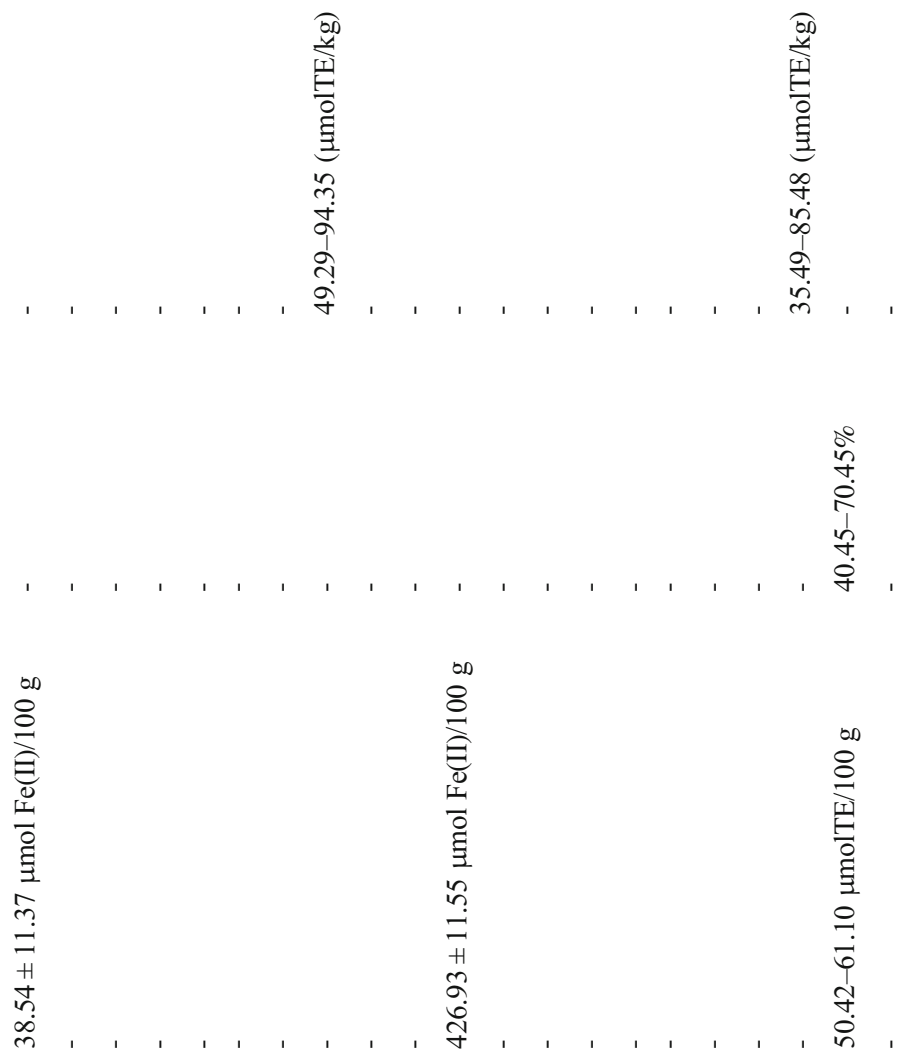

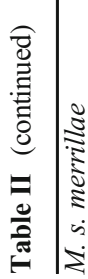
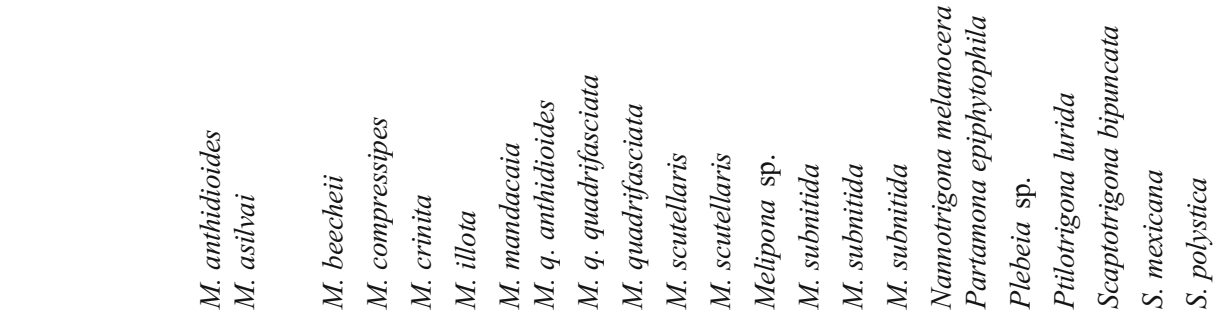


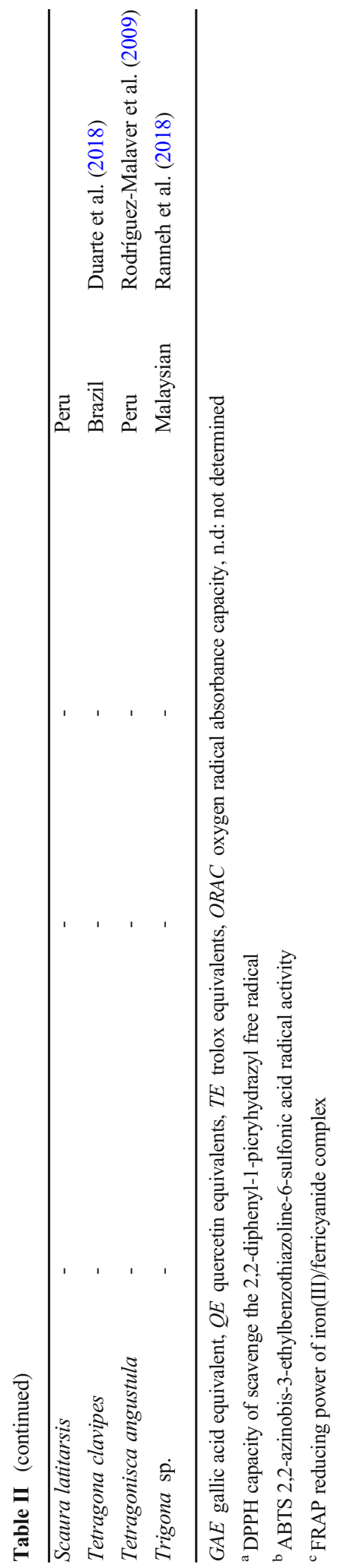

constituents coincided with the honeys from the same floral source. The study reported the presence of the flavonoid taxifoline in honey from stingless bees and the presence of catechol in Brazilian honeys for the first time. In addition, some of the samples showed effective potential in inhibiting microbial growth.

Oliveira et al. (2012) carried out studies on honeys from the state of Pará (Brazil) and found differences in the phenolic content and antioxidant activity using DPPH on samples from different locations for the species M. flavolineata and M. fasciculata. These authors used highperformance liquid chromatography for identification by comparing with standards of compounds present in stingless bee honeys, and found differences in the composition with major constituents of quercetin and gallic acid.

Biluca et al. (2016) determined the content of phenolic compounds in samples of honeys from ten species of stingless bees; in different periods of the year, the variation in the contents of these compounds was justified by the difference in botanical origin; however, the quantification values are shown in graphs, the minimum values being $10.3 \mathrm{mg}$ of gallic acid $100 \mathrm{~g}^{-1}$ and maximum $98 \mathrm{mg}$ of gallic acid $100 \mathrm{~g}^{-1}$ of honey, found for the bees Melipona quadifasciata and Tetragonisca angustula, respectively. Biluca et al. (2017) identified and quantified the presence of mandelic acid, caffeic acid, chlorogenic acid, rosmarinic acid, aromadendrene, isoquercitrin, eriodictyol, vanillin, umbelliferone, syringaldehyde, synap aldehyde, and carnosol in native bee honeys and significant correlation of compounds with antioxidant activity expressed by these honeys. Alvarez-Suarez et al. (2018) identified 19 compounds in $M$. beecheii honey using HPLC-DAD-ESI MS/MS, among those identified were C-pentosyl-C-hexosylapigenin, coumaric acid, isorhamnetin, kaempferol, luteolin, apigenin, quercetin, ferulic acid, and dihydrocaffeic acid.

The aroma of honey, although it seems characteristic, is influenced by the great variety of volatile compounds from floral origin. In addition, several other factors can contribute to the "flavor" of honey, such as the bee's own physiology, as well as procedures after harvest in relation to the heating, storage, and other factors (Campos et al. 
2000). Costa et al. (2018) analyzed honey from Melipona subnitida and M. scutellaris using extraction via HS-SPME and gas chromatography coupled with mass spectrometry and detected a total of 114 volatile compounds, of which the highest contents were terpenes, followed by esters, norisoprenoids, benzene derivatives, furans, ketones, hydrocarbons, alcohols, aldehydes, acids, in addition to a sulfur compound. Although the samples come from different plant origins, the presence of certain compounds in all honeys was noted, and others were detected in the samples of only one of the studied species. Compounds belonging to these classes have also been found in honey from Apis mellifera (Alissandrakis et al. 2007a, b; Alissandrakis et al. 2009; Anastasaki et al. 2009; Ceballos et al. 2010; Jerković et al. 2010a, b; Alissandrakis et al. 2011; Jerković et al. 2011a, b).

Silva et al. (2017) studied the composition of volatiles obtained by static headspace gas chromatography of eight species of bees native to the state of Paraná (Brazil) and identified 44 compounds, including derivatives of linalool, hotrienol, and esters, and attributed the composition to the geographical origin of the samples.

In addition to the anti-toxicity activity, other biological properties have also been investigated, due to the therapeutic use of honey produced by bees of the genus Apis and by stingless bees (Amin et al. 2018). The antimicrobial activity is the category that presents the most data, the honey of Tetragonisca angustula was the most commonly studied. Miorin et al. (2003) performed a microbial sensitivity test against Staphylococcus aureus and obtained a minimum inhibitory concentration that ranged from 142.87 to $214,33 \mathrm{mg} \mathrm{mL}^{-1}$, demonstrating an action lower than that of Apis mellifera, also evaluated in the study. Demera and Angert (2004) used agar diffusion and found that honey significantly inhibited the tested yeasts Saccharomyces cerevisiae (ATCC 287) and Candida albicans (ATCC 90028). Sgariglia et al. (2010) found similar results with growth inhibition of Escherichia coli (IEV301), Pseudomonas aeruginosa (IEV 305), Staphylococcus aureus (IEV7), Staphylococcus aureus (IEV 20), and Enterococcus faecali (IEV 208). Mercês et al. (2013) evaluated the antimicrobial action of honey from $T$. angustula, both by the agar diffusion method and by broth macrodilution, and only obtain activity against $S$. aureus and $E$. coli with a minimum inhibitory concentration equal to $28.2 \mathrm{mg} \mathrm{mL}^{-1}$ and $132 \mathrm{mg} \mathrm{mL}^{-1}$, respectively.

For anti-tumor activity, the results indicate that honeys have significant action with different mechanisms on tumor cell lines (Vit et al. 2013). Kustiawan et al. (2014) evaluated extracts of honey from different species of native bees and all of them presented cytotoxicity on hepatoblastoma cells. Ahmad et al. (2019) induced apoptosis in malignant glioma cells for cytotoxic analysis of Heterotrigone itama honey. The results demonstrated cytotoxicity at certain periods and dosages, since honey induced nuclear shrinkage, chromatin condensation, and nucleus fragmentation. In addition to the cytotoxic action of honey, the investigation of its potential as a chemopreventive agent was carried out by Yazan et al. (2016), whose results showed that honey from Trigona sp. significantly reduced the total number of aberrant crypt foci, aberrant crypts, and multiplicity of colorectal crypts.

Regarding the anti-inflammatory effects, the studies by Borsato et al. (2014) and Ruiz-Ruiz et al. (2017) demonstrated different therapeutic effects that honey can have for this action. Borsato et al. (2014) evaluated the potential of Melipona marginata honey in reducing ear inflammation in test subjects and observed that the topical application of honey extract $(1.0 \mathrm{mg} / \mathrm{ear})$ was able to reduce ear edema. This extract decreased myeloperoxidase activity, which suggests a lower leukocyte infiltration and was confirmed by histological analysis. In addition, it also provided a reduction in the production of reactive oxygen species. Ruiz-Ruiz et al. (2017) carried out an in vitro determination using the evaluation of protein denaturation and observed that the flavonoid fraction of the methanol extract showed itself to be potent in inhibiting the denaturation of albumin and in membrane stabilization.

Ilechie et al. (2012) used different concentrations of fresh honey from Meliponula ssp. to treat bacterial conjunctivitis caused by Staphylococcus aureus or Pseudomonas aeruginosa induced in vivo in Hartley guinea pigs and found that the effect of honey was comparable with that of gentamicin, a standard antibiotic. In view of the 
results, the authors suggest the use of honey as an alternative treatment for infections. Similar results were found by Kwapong et al. (2013) with Meliponula bucandei honey, which showed antimicrobial activity in vitro against bacteria isolated from eye infections (Staphylococcus aureus, Staphylococcus epidermidis, and Pseudomonas aeruginosa). The inhibitory effect of honey in reducing inflammation and infection was superior to the commonly used ophthalmic antibiotics.

Kwakman et al. (2010) suggest that the bioactive properties of honey are attributed to specific factors, such as the synergistic action of sugar and hydrogen peroxide for wound healing. In studies carried out with Apis mellifera honey, the samples that suffered a decrease in the accumulated $\mathrm{H}_{2} \mathrm{O}_{2}$ levels had a marked reduction in the antibacterial action against Staphylococcus aureus, Escherichia coli, and Pseudomonas aeruginosa resistant strains. According to the authors, this indicates that $\mathrm{H}_{2} \mathrm{O}_{2}$ is important for the bactericidal activity of honey, but additional factors must also be present. For Yaghoobi et al. (2013), honey induces leukocytes to release cytokines, which initiate tissue repair cascades, in addition to activating the immune response to infection.

An outstanding finding was done recently by Fletcher et al. (2020) about the sugar composition of stingless bee honey. They found a high concentration of trehalulose, between 13 to $44 \mathrm{~g}$ per $100 \mathrm{~g}$, in honey from five different stingless bee species across Neotropical and Indo-Australian regions. Trehalulose is a specific kind of disaccharide, considered to be beneficial for human health because of its acariogenic and low glycemic index properties. Besides, it is $70 \%$ as sweet as sucrose and not readily crystallized, therefore has commercial application in food industry (Fletcher et al. 2020).

\section{FUTURE PERSPECTIVES}

Significant differences are found between the stingless bee honey and Apis mellifera honey, as well as between the different species of stingless bees. This reinforces the need to develop rules and regulations aimed exclusively at determining the quality of honey from stingless bees. The growing demand for products from stingless bee also justifies additional studies and more complete approaches, due to the large number of species that are still poorly studied or that have not even been studied yet. Additional conservation treatments should be considered to increase the shelf life of honey, as well as to facilitate commercialization by informal producers. The chemical profile of native bee honeys has been little explored, which limits the quantification of classes of compounds, so more comprehensive studies regarding chemical characterization are needed. The advancement of scientific knowledge related to the particularities of honey of each species of stingless bee will be of fundamental importance in order to increase the value of its products, especially if it is conducted to identify and enhance regional aspects. This type of study has an urgent appeal in view of the current scenario in which the importance of conservation of the environment has been much questioned worldwide. As such, it will allow honey farmers to generate income effectively from the standing forest.

\section{AUTHORS' CONTRIBUTIONS}

ECAS and AF discussion of chemical data and wrote the paper and participated in the revisions of it; CM discussion of aspects of morphology, management, and conservation of stingless bees.

Miel d'abeille sans dard (Hyménoptères, Apidés, Méliponnes): Un examen du contrôle de la qualité, du profil chimique et du potentiel biologique.

abeilles sans dard / qualité du miel / composition chimique.

Honig von Stachellosen Bienen (Hymenoptera, Apidae, Meliponini): Ein Review über Qualitätskontrolle, chemisches Profil und biologisches Potential.

Stachellose Bienen / Honigqualität / chemische Zusammensetzung.

\section{REFERENCES}

Abu Bakar MF, Sanusi SB, Abu Bakar FI, Cong OJ, Mian Z (2017) Physicochemical and antioxidant potential of raw unprocessed honey from Malaysian stingless bees. 
Pak. J. Nutr., 16(11):888-894. https://doi.org/10. 3923/pjn.2017.888.894.

Ahmad F, Seerangan P, Mustafa MZ, Osman ZF, Abdullah JM, Idris Z (2019) Anti-cancer properties of Heterotrigona itama sp. honey via induction of apoptosis in malignant glioma cells. Malays J. Med. Sci., 26 (2):30-39. https://doi.org/10.21315/mjms2019.26. 2.4 .

Alissandrakis E, Tarantilis PA, Harizanis PC, Polissiou M (2007a) Aroma investigation of umifloral Greek citrus honey using solid-phase microextraction coupled to gas chomatographic-mass spectrometric analysis. Food Chem., 100 (1):396-404. https://doi.org/10. 1016/j.foodchem.2005.09.015.

Alissandrakis E, Tarantilis PA, Harizanis PC, Polissiou M (2007b) Comparison of the volatile composition in thyme honeys from several origins in Greece. J. Agric. Food Chem., 55: 8152-8157. https://doi.org/10.1021/ jf071442y.

Alissandrakis E, Tarantilis PA, Pappas C, Harizanis PC, Polissiou M (2009) Ultrasound-assisted extraction gas chromatography-mass spectrometry analysis of volatile compounds in unifloral thyme honey from Greece. Eur. Food Res. Technol., 229 :365-373. https://doi.org/ 10.1007/s00217-009-1046-8.

Alissandrakis E, Tarantilis PA, Pappas C, Harizanis PC, Polissiou M (2011) Investigation of organic extractives from unifloral chestnut (Castanea sativa L. ) and eucalyptus (Eucalyptus globulus Labill.) honeys and flowers to identification of botanical marker compounds. Food Sci. Technol., $44: 1042-1051$. https:// doi.org/10.1016/j.lwt.2010.10.002.

Almeida-Muradian LB, Stramm KM, Horita A, Barth OM, Freitas AS, Estevinho LM (2013) Comparative study of the physicochemical and palynological characteristics of honey from Melipona subnitida and Apis mellifera. Int. J. Food Sci. Technol., 48(8):16981706. https://doi.org/10.1111/ijfs.12140.

Alvarez-Suarez JM, Giampieri F, Brenciani A et al (2018) Apis mellifera vs Melipona beecheii Cuban polifloral honeys: A comparison based on their physicochemical parameters, chemical composition and biological properties. LWT Food Sci. Technol., https://doi.org/10. 1016/j.lwt.2017.08.079.

Alves RMO, Carvalho CAL, Souza BDA, Sodré GDS, Marchini LC (2005) Características físico-químicas de amostras de mel de Melipona mandacaia Smith (Hymenoptera: Apidae). Ciênc. Tecnol. Aliment., 25 (4):644-650.

Alves EM, Fonseca AAO, dos Santos PC, Bitencourt RM, Sodré GS, Carvalho CAL (2012) Estabilidade físicoquímica e sensorial de méis desumidificado de Tetragonisca angustula. Magistra, 24 :185-193.

Amin FAZ, Sabri S, Mohammad SM, Ismail M, Chan KW, Ismail N, Norhaizan ME, Zawawi N (2018) Therapeutic Properties of Stingless Bee Honey in Comparison with European Bee Honey. Adv. Pharmacol. Sci., Article ID: 6179596. https://doi.org/10.1155/2018/ 6179596.
Anacleto DDA, Souza BDA, Marchini LC, Moreti ACDCC (2009) Composição de amostras de mel de abelha Jataí (Tetragonisca angustula latreille, 1811). Ciênc. Tecnol. Aliment., 29(3):535-54.

Anastasaki E, Kanakis C, Pappas C, Maggi L, del Campo CP, Carmona M, Alonso GL, Polissiou MG (2009) Geographical differentiation of saffron by GC-MS/ FID and chemometrics. European Food Research and Technology 229 (6):899-905.

Anjum SI, Ullah A, Khan KA, Attaullah M, Khan H et al (2018) Composition and functional properties of propolis (bee glue): A review. Saudi J. Biol. Sci., 26 (7):1695-1703. https://doi.org/10.1016/j.sjbs.2018. 08.013 .

Ávila S, Hornunga PS, Teixeira GL, Malunga LN, ApeaBah FB, Beux MR, Beta T, Ribani RH (2019) Bioactive compounds and biological properties of Brazilian stingless bee honey have a strong relationship with the pollen floral origin. Food Res. Int., $123: 1-10$. https:// doi.org/10.1016/j.foodres.2019.01.068.

Bartelli BF, Nogueira-Ferreira FH (2014) Pollination Services Provided by Melipona quadrifasciata Lepeletier (Hymenoptera: Meliponini) in Greenhouses with Solanum lycopersicum L. (Solanaceae). Sociobiology, 61 (4): 510-516. https://doi.org/10.13102/sociobiology.v61i4.510-516.

Bastos DHM, dos Santos MC, Mendonça MS, Torres EAFS (2009) Antioxidant Capacity and Phenolic Content of Stingless Bee Honey from Amazon in Comparison to Apis Bee Honey. Acta Hortic., 841 : 83-486. https://doi.org/10.17660/ActaHortic.2009.841.64.

Biluca FC, Braghini F, Gonzaga LV, Costa ACO, Fett R (2016) Physicochemical profiles, minerals and bioactive compounds of stingless bee honey (Meliponinae). J. Food Compos. Anal., 50:61-69. https://doi.org/10. 1016/j.jfca.2016.05.007.

Biluca FC, Gois JS, Schulza M et al (2017) Phenolic compounds, antioxidant capacity and bioaccessibility of minerals of stingless bee honey (Meliponinae). J. Food Compos. Anal., 63 :89-97. https://doi.org/10. 1016/j.jfca.2017.07.039.

Blettler DC, Fagúndezo GA, Caviglia OP (2018) Contribution of honeybees to soybean yield. Apidologie, $49: 101-111$. https://doi.org/10.1007/s13592-017$0532-4$.

Borsato DM, Prudente AS, Boscardin PM et al (2014) Topical Anti-inflammatory Activity of a Monofloral Honey of Mimosa scabrella provided by Melipona marginata During Winter in Southern Brazil. J. Med. Food, 17 (7):817-825. https://doi.org/10.1089/jmf. 2013.0024

BRAZIL (2000) Ministério da Agricultura Pecuária e Abastecimento. Instrução Normativa ${ }^{\circ} 11$, de 20 de outubro de 2000. Regulamento técnico de identidade e qualidade do mel. Diário Oficial, Brasília, 20 de outubro de 2000, Seção 001, p.16-17.

BRAZIL (2014) Agência Estadual de Defesa Agropecuária da Bahia - ADAB. Regulamento Técnico de Identidade e Qualidade do Mel de Abelha social sem ferrão, gênero Melipona [online] https://www. 
legisweb.com.br/legislacao/?id=277684 (accessed on 16 Jul 19).

BRAZIL (2016) Agência de Defesa Agropecuária e Florestal do Estado do Amazonas - Adaf/Am. Regulamento Técnico de Identidade e Qualidade do Mel de Abelha Social Sem Ferrão [online] https:// www.escavador.com/diarios/DOEAM (accessed on 01 Nov 2018).

BRAZIL (2017) Secretaria de Agricultura e abastecimento. Resolução SAA - 52, de 3-10-2017. regulamento técnico de identidade, o padrão de qualidade e os requisitos do processo de beneficiamento do mel, destinado ao consumo humano elaborado pelas abelhas da subfamília Meliponinae (Hymenoptera, Apidae), conhecidas como abelhas sem ferrão. Diário Oficial, São Paulo, 06 de outubro de 2017, Seção 1, p.127.

Camargo RCR, Oliveira KL, Berto MI (2017) Mel de abelhas sem ferrão: proposta de regulamentação. Braz. J. Food Technol. 20, e2016157. https://doi.org/10. 1590/1981-6723.15716

Campos G, Nappi GU, Raslan DS, Augusti R (2000) Substâncias voláteis em mel floral e mel de melato. Ciênc. Tecnol. Aliment., 20 (1):18-22. https://doi.org/ 10.1590/S0101-20612000000100004.

Campos G, Della-modesta RC, Silva TJP, Baptista KE, Gomides MF, Godoy RL (2003) Classificação do mel em floral ou mel de melato . Ciênc. Tecnol. Aliment., 23 (1): 1-5. https://doi.org/10.1590/S010120612003000100002.

Carvalho CAL, Sodré GS, Fonseca AAO, Alves RMO, Souza BA, Clarton L (2009) Physicochemical characteristics and sensory profile of honey samples from stingless bees (Apidae: Meliponinae) submitted to a dehumidification process. An. Acad. Bras. Cienc., 81 (1):143-149. https://doi.org/10.1590/S000137652009000100015.

Castro MS, Koedam D, Contrera FAL et al (2006) Bee management for pollination purposes: Stingless bees, In: Imperatriz-Fonseca VL, Saraiva AM, De Jong D. (ed), Bees as pollinators in Brazil: assessing the status and suggesting best practices. Holos Editora, Ribeirão Preto, 75-88.

Ceballos L, Pino JA, Quijano-Celis CE, Dago A. (2010) Optimization of a HS-SPME/GC-MS method for determination of volatile compounds in some Cuban unifloral honeys. J. Food Qual., 33 : 507-528. https:// doi.org/10.1111/j.1745-4557.2010.00330.x

Chuttong B, Chanbang Y, Sringarm K, Burgett M (2016) Physicochemical profiles of stingless bee (Apidae: Meliponini) honey from South East Asia (Thailand). Food Chem.,192:149-155. https://doi.org/10.1016/j. foodchem.2015.06.089.

Codex Alimentarius Commission (2001). Codex Alimentarius commission standards. Codex Stan., 12-1981, 1-8.

Contrera FAL, Menezes C, Venturieri GC (2011) New horizons on stingless beekeeping (Apidae, Meliponini). R. Bras. Zootec., $40: 48-51$.
Costa ACV, Sousa JMB, Bezerra TKA, Silva FLH, Pastore GM, Silva MAAP, Madruga MS (2018) Volatile profile of monofloral honeys produced in Brazilian semiarid region by stingless bees and key volatile compounds. Food Sci. Technol., 94 :198-207. https://doi. org/10.1016/j.lwt.2018.04.043.

de Almeida-Muradian LB, Matsuda AH (2007) Physicochemical parameters of Amazon Melipona honey. Quim Nova 30 (3):707-708. https://doi.org/10.1590/ S0100-40422007000300033.

Demera J, Angert E (2004) Comparison of the antimicrobial activity of honey produced by Tetragonisca angustula (Meliponinae) and Apis mellifera from different phytogeographic regions of Costa Rica. Apidologie, 35 (4):411-417. https://doi.org/10.1051/ apido:2004033.

Do Vale MAD, Gomes FA, Dos Santos BRC, Ferreira JB (2018) Honey quality of Melipona sp. bees in Acre. Acta Agron., 67 (2):201 207. https://doi.org/10.15446/ acag.v67n2.60836.

Duarte AWF, Vasconcelos MRS, Oda-Souza M, Oliveira FF, López AMQ (2018) Honey and bee pollen produced by Meliponini (Apidae) in Alagoas, Brazil: multivariate analysis of physicochemical and antioxidant profiles. Food Sci. Technol., 38(3):493-503. https:// doi.org/10.1590/fst.09317.

Evangelista-Rodrigues A, Silva EMSDA, Beserra EMF, Rodrigues ML (2005) Análise físico-química dos méis das abelhas Apis mellifera e Melipona scutellaris produzidos em regiões distintas no Estado da Paraíba. Cien. Rural, 35 (5):1166-1171. https://doi.org/10. 1590/S0103-84782005000500028.

Fletcher MT, Hungerford NL, Webber D, Jesus MC, Zhang J, Stone ISJ, Blanchfield JT, Zawawi N (2020) Stingless bee honey, a novel source of trehalulose: a biologically active disaccharide with health benefits. Scientific Reports 10 (1).

Freitas BM, Nunes-Silva P (2012) Polinização Agrícola e sua Importância no Brasil In: Polinizadores no Brasil contribuição e perspectivas para a biodiversidade, uso sustentável, conservação e serviços ambientais. Ed. São Paulo: EDUSP, pp. 103-118.

Freitas WES, Aroucha EMM, Soares KMP, Mendes FIB, Oliveira VR, Lucas CR, Santos MCA (2010) Physicalchemical parameters of honey stingless bee (Melipona subnitida) after heat treatment. Acta Vet. Bras., $4(3): 153-157$.

Fuenmayor CA, Zuluaga-Domínguez CM, Díaz-Moreno AC, Quicazán MC (2012) Miel de Angelita: Nutritional composition and physicochemical properties of Tetragonisca angustula honey. Interciencia, 37 (2):142-147.

Gilliam M, Buchmann SL, Lorenz BJ, Roubik DW (1985) Microbiology of the Larval Provisions of the Stingless Bee, Trigona hypogea, an Obligate Necrophage. Biotropica, 17 (1):28-31. https://doi.org/10.2307/ 2388374.

Gilliam M, Roubik DW, Lorenz BJ (1990) Microorganisms associated with pollen, honey, and brood provisions in the nest of a stingless bee, Melipona fasciata . 
Apidologie, 21 (2):89-97. https://doi.org/10.1051/ apido: 19900201 .

Heard TA (1999) The role of stingless bees in crop pollination. Annu. Rev. Entomol., 44:183-206. https://doi. org/10.1146/annurev.ento.44.1.183.

Ilechie AA, Kwapong PK, Mate-Kole E, Kyei S, DarkoTakyi C (2012) The efficacy of stingless bee honey for the treatment of bacteria-induced conjunctivitis in guinea pigs. J. Exp. Pharmacol., 4 :63-68. https://doi. org/10.2147/JEP.S28415,

Imperatriz-Fonseca VL, Nunes-Silva P (2010) As abelhas, os serviços ecossistêmicos e o Código Florestal Brasileiro. Biota. Neotrop., 10 (4):59-62. https://doi. org/10.1590/S1676-06032010000400008.

Issaro N, Weerakul T, Machana S et al (2013) Stingless bee honey II: Qualitative and quantitative studies on honey produced by three stingless bee species collected from a Mangosteen garden in Chantaburi province, Thailand. Thai J. Pharm. Sci., $38: 16-18$.

Jaffé R, Pope N, Carvalho AT et al (2015) Bees for Development: Brazilian Survey Reveals How to Optimize Stingless Beekeeping. PLoS One, 10(3):e0121157. https://doi.org/10.1371/journal.pone.0121157.

Jerković I, Tuberso CIG, Gugić M, Bubalo D (2010a) Composition of Sulla (Hedysarum coronarium L.) Honey Solvent Extractives Determined by GC/MS: Norisoprenoids and Other Volatile Organic Compounds. Molecules 15(9):6375-6385.

Jerković I, Marijanović Z, Malenica-Staver M, Lušić D (2010b) Volatiles from a Rare Acer spp. Honey Sample from Croatia. Molecules 15(7):4572-4582.

Jerković I, Marijanović Z, Staver MM (2011a) Screening of natural organic volatiles from Prunus mahaleb L. honey: coumarin and vomifoliol as nonspecific biomarkers. Molecules, 16: 2507-2518. https://doi.org/ 10.3390/molecules 16032507 .

Jerković I; Kasum A, Marijanović Z, Tuberoso CIG (2011b) Contribution to the characterisation of honey-based Sardinian product abbamele: volatile aroma composition, honey marker compounds and antioxidant activity. Food Chem., $124: 401-410$. https://doi. org/10.1016/j.foodchem.2010.06.047.

Jimenez M, Beristain CI, Azuara E, Mendoza MR, Pascual LA (2016) Physicochemical and antioxidant properties of honey from Scaptotrigona Mexicana bee. J. Apic. Res., 8839:1-10. https://doi.org/10.1080/00218839. 2016.1205294.

Kerr WE, Carvalho GA, Silva AC, Assis MGP (2001) Aspectos pouco mencionados da biodiversidade amazônica. Parcerias Estratégicas, 6 (12):20-41.

Kiatoko N, Raina SK, Muli E, Mueke J (2014) Enhancement of fruit quality in Capsicum annum through pollination by Hypotrigona gribodoi in Kakamega, Western Kenya. J. Entomol. Sci., 17:106-110. https://doi.org/10.1111/ens.12030.

Kustiawan PM, Songchan P, Enos TA, Chanpen C (2014) In Vitro Cytotoxicity of Indonesian Stingless Bee Products against Human Cancer Cell Lines. Asian
Pac. J. Trop. Biomed., 16(1):134-140. https://doi. org/10.12980/APJTB.4.2014APJTB-2013-0039.

Kwakman PHS, te Velde AA, de Boer L, Speijer D, Vandenbroucke-Grauls CMJE, Zaat SAJ (2010) How honey kills bactéria. FASEB J., 24 (7):2576-82. https:// doi.org/10.1096/fj.09-150789.

Kwapong PK, Ilechie AA, Kusi R (2013) Comparative antibacterial activity of stingless bee honey and standard antibiotics against common eye pathogens. J. Microbiol. Biotech. Res., 3 (1):9-15.

Lage LGA, Coelho LL, Resende HC et al (2012) Honey physicochemical properties of three species of the Brazilian Melipona. An. Acad. Bras. Cienc., 84(3):605608 . https://doi.org/10.1590/S000137652012005000051.

Lemos MS; Venturieri GC, Dantas Filho HA, Dantas KGF (2017) Evaluation of the physicochemical parameters and inorganic constituents of honeys from the Amazon region. J. Apic. Res., 57 (1):1-10. https://doi.org/10. 1080/00218839.2017.1338120.

Menezes C, Vollet-Neto A, Contrera FAFL, Venturieri GC, Imperatriz-Fonseca VL (2013) The Role of Useful Microorganisms to Stingless Bees and Stingless Beekeeping, in: Vit P, Pedro S, Roubik D (ed), Pot-Honey. Springer, New York.

Menezes BAD, Mattietto RA, Lourenço LFH (2018) Evaluation of quality of honey from africanized and stingless bees natives of the northeast of the state of Pará. Cienc. Anim. Bras., 19:1-13. https://doi.org/10.1590/ 1809-6891v19e-46578.

Mercês MD, Peralta ED, Uetanabaro AP, Lucchese AM (2013) Antimicrobial activity of honey from five species of Brazilian stingless bees. Cien. Rural, 43 (4):672-675. https://doi.org/10.1590/S010384782013005000016.

Miorin PL, Levy Junior NC, Custodio AR, Bretz WA, Marcucci MC (2003) Antibacterial activity of honey and propolis from Apis mellifera and Tetragonisca angustula against Staphylococcus aureus. J. Appl. Microbiol., 95 :913-920. https://doi.org/10.1046/j. 1365-2672.2003.02050.x.

Nascimento A, Marchini L, Carvalho C, Araújo D, Olinda R, Silveira T (2015) Physical-chemical parameters of honey of stingless bee (Hymenoptera: Apidae). Am. Chem. Sci. J., 7 (3):139-149. https://doi.org/10.9734/ $\mathrm{ACSj} / 2015 / 17547$.

Nogueira-Neto P (1997) Vida e criação de abelhas indígenas sem ferrão. Nogueirapis, São Paulo.

Nweze JA, Okafor JI, Nweze EI, Nweze JE (2017) Evaluation of physicochemical and antixidant properties of two stingless bee honeys: A comparison with with Apis mellifera honey from Nsukka, Nigeria. BMC Res. Notes, $10: 1-6$. https://doi.org/10.1186/s13104-0172884-2.

Oliveira ENA, Santos DC (2011) Physical-chemical analysis of honeys from africanized and native bees. Rev Inst Adolfo Lutz, 70 (2):132-138.

Oliveira PS, Müller RCS, Dantas KGF, Alves CN, De Vasconcelos MAM, Venturieri GC (2012) Ácidos 
fenólicos, flavonoides e atividade antioxidante em méis de Melipona fasciculata, M. flavolineata (Apidae, Meliponini) E Apis mellifera (Apidae, Apini) da Amazônia. Quim Nova, 35 (9):1728-1732. https:// doi.org/10.1590/S0100-40422012000900005.

Oliveira RG, Jain S, Luna AC, Freitas LS, Araujo ED (2017) Screening for quality indicators and phenolic compounds of biotechnological interest in honey samples from six species of stingless bees (Hymenoptera: Apidae). Food Sci. Technol., 37 (4):552-557. https:// doi.org/10.1590/1678-457X.25716.

Ollerton J, Winfree R, Tarrant S. How many flowering plants are pollinated by animals? (2011) Oikos, $120: 321-326$. https://doi.org/10.1111/j.1600-0706. 2010.18644.x.

Persano Oddo P, Heard T, Rodríguez-Malaver A, Pérez R A et al (2008) Composition and antioxidant activity of Trigona carbonaria honey from Australia. J. Med. Food, 11 (4), 789-794. https://doi.org/10.1089/jmf. 2007.0724 .

Popova M, Trusheva B, Bankova V (2019) Propolis of stingless bees: A phytochemist's guide through the jungle of tropical biodiversity. Phytomedicine, $27: 153098$. https://doi.org/10.1016/j.phymed.2019. 153098 .

Potts SG, Imperatriz-Fonseca V, Ngo HT et al (2016) Safeguarding pollinators and their values to human well-being. Nature, $540: 220-229$. https://doi.org/10. 1038/nature20588.

Pucciarelli AB, Schapovaloff ME, Kummritz S, Señuk I, Brumovsky L, Dallagnol AM (2014) Microbiological and physicochemical analysis of yateí (Tetragonisca angustula) honey for assessing quality standards and commercialization. Rev. Argent. Microbiol., 46 (4):325-332.

Ranneh Y, Ali F, Zarei M, Akim ABM, Hamid HA, Khazaai H (2018) Malaysian stingless bee and Tualang honeys: A comparative characterization of total antioxidant capacity and phenolic profile using liquid chromatography-mass spectrometry. LWT-Food Sci. Technol., 89:1-9. https://doi.org/10.1016/j.lwt.2017. 10.02089 .

Rodríguez-Malaver A, Rasmussen C, Gutiérrez M, Gil F, Nieves B, Vit P (2009) Properties of honey from ten species of Peruvian stingless bees. Nat. Prod. Commun., 4 (9):1221-1226.

Roselino AC, Santos SB, Hrncir M, Bego LR (2009) Differences between the quality of strawberries (Fragaria $x$ ananassa) pollinated by the stingless bees Scaptotrigona aff. depilis and Nannotrigona testaceicornis. Genet. Mol. Res., 8(2), 539-545.

Roselino AC, Santos SB, Hrncir M, Bego LR (2010) Qualidade dos frutos de pimentão (Capsicum annuum L.) a partir de flores polinizadas por abelhas sem ferrão (Melipona quadrifasciata anthidioides Lepeletier 1836 e Melipona scutellaris Latreille 1811) sob cultivo protegido. R. Bras. Bioci., 8 (2):154-158.

Ruiz-Ruiz JC, Matus-Basto AJ, Acereto-Escoffié P, Segura-Campos MR (2017) Antioxidant and anti-inflammatory activities of phenolic compounds isolated from Melipona beecheii honey. Food Agric. Immunol., 28(6):1424-1437. https://doi.org/10.1080/ 09540105.2017 .1347148 .

Santisteban RM, Cabrera SP, Neto JF et al (2019) Análises melissopalinológicas, físico-químicas, atividade antirradicalar e perfil químico por UPLC-DADQTOF-MS/MS dos méis de Frieseomelitta doederleini (abelha branca): comparação com os fenólicos presentes nas flores de Mimosa tenuiflora (jurema preta). Quim Nova, 42 (8):874-884. https:// doi.org/10.21577/0100-4042.20170407.

Seeley TD (1985) Honeybee Ecology: A Study of Adaptation in Social Life. Princeton University Press.

Sgariglia MA, Vattuone MA, Sampietro-Vattuone MM, Soberón JR, Sampietro DA (2010) Properties of honey from Tetragonisca angustula fiebrigi and Plebeia wittmanni of Argentina. Apidologie, 41 (6), 667675. https://doi.org/10.1051/apido/2010028.

Silva IAA, Silva TMS, Camara CA et al (2013) Phenolic profile, antioxidant activity and palynological analysis of stingless bee honey from Amazonas, Northern Brazil . Food Chem., 141 :3552-3558. https://doi.org/10. 1016/j.foodchem.2013.06.072.

Silva PLM, Lima LS, Caetano IK, Torres YR (2017) Comparative analysis of the volatile composition of honeys from Brazilian stingless bees by static headspace $\mathrm{GC}-$ MS. Food Res. Int.,102 : 536-543. https://doi.org/10. 1016/j.foodres.2017.09.036.

Slaa EJ, Sánchez-Chaves LA, Malagodi-Braga KS, Hofstede FE (2006) Stingless bees in applied pollination: practice and perspectives. Apidologie, 37 :293315. https://doi.org/10.1051/apido:2006022.

Sousa JMB, Aquino IS, Magnani M, Albuquerque JR, dos Santos GG, de Souza, EL (2013) Physicochemical aspects and sensory profile of stingless bee honeys from Seridó region, State of Rio Grande do Norte, Brazil. Semin. Cienc. Agrar., 34 (4):1765-1774. https://doi.org/10.5433/1679-0359.2013v34n4p1765.

Souza BA, Carvalho CAL, Sodré GDS, Marchini LC (2004) Características físico-químicas de amostras de Mel de Melipona asilvai (Hymenoptera: Apidae). Cien. Rural, 34 (5):1623-1624.

Souza B, Roubik D, Barth O et al (2006) Composition of Stingless Bee Honey: Setting Quality Standards. Interciencia, 31 (12), 867-875.

Souza BA, Marchini LC, Oda-Souza M, de Carvalho CL, Alves RMO (2009a) Caracterização do mel produzido por espécies de Melipona Illiger, 1806 (apidae: Meliponini) da região nordeste do brasil: 1 . Características físico-químicas. Quim Nova, 32 (2)303-308. https://doi.org/10.1590/S010040422009000200007.

Souza B, Marchini L, Tadeu C et al (2009b) Avaliação microbiológica de amostras de mel de trigoníneos (Apidae: Trigonini) do Estado da Bahia. Ciênc. Tecnol. Aliment., 29(4):798-802. https://doi.org/10. 1590/S0101-20612009000400015.

Souza RR, Abreu VHR, de Novais JS (2019) Melissopalynology in Brazil: a map of pollen types and published productions between 2005 and 2017 . 
Palynology, 43 (4):690-700 https://doi.org/10.1080/ 01916122.2018 .1542355 .

Suntiparapop K, Prapaipong P, Chantawannakul P (2015) Chemical and biological properties of honey from Thai stingless bee (Tetragonula leaviceps). J. Apic. Res., 51 (1):45-52. https://doi.org/10.3896/IBRA.1.51.1.06.

Venturieri GC, Oliveira PS, Vasconcelos MAM, Mattietto RA (2007) Caracterização, colheita, conservação e embalagem de méis de abelhas indígenas sem ferrão. Embrapa Amazônia Oriental; Belém, Brasil. 51 pp.

Vit P, Bogdanov S, Kilchenmann V (1994) Composition of venezuelan honeys from stingless bees (Apidae: Meliponinae ) and Apis mellifera L. Apidologie, 25 (3):278-288.

Vit P, Persano Oddo L, Marano ML, Mejias ES (1998) Venezuelan stingless bee honeys characterized by multivariate analysis of physicochemical properties. Apidologie, $29: 377-389$.

Vit P , Yu JQ, Huq F (2013). Use of Honey in Cancer Prevention and Therapy. In: Vit P, Pedro SRM, Roubik DW (eds.), Pot-Honey: A legacy of stingless bees. Springer New York, Jan 16, 2013 - Science - 697 pages.
Vollet-Neto A, Koffler S, dos Santos CF, Menezes C, Nunes FMF, Hartfelder K, Imperatriz-Fonseca VL, Alves DA (2018) Recent advances in reproductive biology of stingless bees. Insect. Soc., $65: 201-212$. https://doi.org/10.1007/s00040-018-0607-x.

Yaghoobi R, Kazerouni A, Kazerouni O (2013) Evidence for Clinical Use of Honey in Wound Healing as an Anti-bacterial, Anti-inflammatory Anti-oxidant and Anti-viral Agent: A Review. Jundishapur J. Nat. Pharm. Prod., 8 (3):100-104. https://doi.org/10.17795/ jjnpp-9487.

Yazan LS, Muhamad Zali MFS, Ali RM, Zainal NA, Esa N., Sapuan S, et al. (2016) Chemopreventive properties and toxicity of Kelulut honey in sprague dawley rats induced with azoxymethane. Biomed. Res. Int., 2016, Article ID 4036926:6. https://doi.org/10.1155/ $2016 / 4036926$

Publisher's note Springer Nature remains neutral with regard to jurisdictional claims in published maps and institutional affiliations. 